\title{
La division des savoir-faire textiles entre Indiens et Métis dans la Sierra de Puebla (Mexique)
}

\section{Marie-Noëlle Chamoux}

\section{(2) OpenEdition \\ 12 Journals}

Édition électronique

URL : https://journals.openedition.org/tc/1027

DOI : $10.4000 /$ tc. 1027

ISSN : 1952-420X

Éditeur

Éditions de l'EHESS

\section{Édition imprimée}

Date de publication : 1 septembre 1983

ISSN : 0248-6016

\section{Référence électronique}

Marie-Noëlle Chamoux, «La division des savoir-faire textiles entre Indiens et Métis dans la Sierra de Puebla (Mexique) », Techniques \& Culture [En ligne], 2 | 1983, mis en ligne le 26 janvier 2006, consulté le 29 septembre 2022. URL : http://journals.openedition.org/tc/1027 ; DOI : https://doi.org/10.4000/tc. 1027

Ce document a été généré automatiquement le 29 septembre 2022.

Tous droits réservés 
La division des savoir-faire textiles entre Indiens et Métis dans la Sierra de Puebla (Mexique)

Marie-Noëlle Chamoux 